\title{
Investigating the Existence of a Bubble in the Kenyan Real Estate Market
}

\author{
Paul Kiarie Njoroge, Jane Akinyi Aduda, Carol Mugo \\ Department of Statistics and Actuarial Sciences, Jomo Kenyatta University of Agriculture and Technology, Nairobi, Kenya \\ Email address: \\ paulkiarie03@gmail.com (P. K. Njoroge)

\section{To cite this article:} \\ Paul Kiarie Njoroge, Jane Akinyi Aduda, Carol Mugo. Investigating the Existence of a Bubble in the Kenyan Real Estate Market. \\ International Journal of Data Science and Analysis. Vol. 4, No. 5, 2018, pp. 89-97. doi: 10.11648/j.ijdsa.20180405.13
}

Received: October 11, 2018; Accepted: October 23, 2018; Published: November 21, 2018

\begin{abstract}
In the Kenyan real estate industry, laws of economics seem to be violated. The demand for houses has been increasing tremendously despite the oversupply. This violates the laws of economics indicating a possibility of a real estate bubble. The study aimed at estimating short term and long term real estate price dynamics in Kenya using co-integration tests. Secondly, the study aimed at identifying the presence of a Kenyan real estate bubble using the forward-recursive Generalized Augmented Dickey-Fuller test (GSADF) and finally measured the size of the bubble at a given time relative to other key macroeconomic variables. The study utilized quarterly data on house prices and rental prices in Kenya and macroeconomic determinants from the year 2004 to 2017 September. Stationarity test revealed that the variables were stationary in their first difference I (1). Cointegration test revealed that there was no long term and short term house price dynamics between house prices and the macroeconomic variables at a lag of 4 determined through AIC, SIC and HQ criterion. Again a Granger causality test was performed and the results revealed that the macroeconomic variables did not Granger-cause house prices and vice versa. To investigate the presence of a Kenyan real estate bubble, cointegration test, and GSADF were performed and the results indicated the existence of a bubble in the Kenyan real estate. Two time period bubbles were identified from September 2009 to January 2010 and the other from April 2011 to September 2011. Finally, the bubble sizes were measured and were found to be $15 \%$ each in the two periods.
\end{abstract}

Keywords: Bubble, Real Estate, Generalized Supremum ADF, Cointegration, Vector Error Correction Model (VECM)

\section{Introduction}

Real estate market plays a very important role in any economy and has become an interest for several investors across the world. In the recent past, it has contributed greatly towards Kenya's Gross Domestic Product (GDP) standing at $4.8 \%$ in 2013 up from $2.8 \%$ in 2007 as cited in [1]. A study carried out by Center for Affordable Housing Finance in Africa (CAHF) estimated that in Kenya, the town population has risen at a rate of $4.2 \%$ yearly leading to an increase in house demand. By 2010, it was 120,000 units were approximated to be on demand every year and only 35,000 units were being met [2]. This has led to a tremendous increase in housing price. According to a study carried out by Center for Affordable Housing Finance in Africa (CAHF), out of the 71 cities that were surveyed in the prime international residential index in 2012, Nairobi and the coastal regions were said to have reported a double increase in the price of the property market [3]. A recent study carried out by Hass consult, a renown real estate agent in Kenya, reported that property values had increased by 3.37 times from 2000 to 2013 [4].

In Kenya, especially the major urban centers, the real estate prices seem to have been over-valued. The laws of demand and supply seem to have been violated as there is a high demand for housing irrespective of the existing oversupply of houses on the other hand. The prices have risen and are rising to very high levels which are not sustainable. According to a study by Case and Shiller, future expectations by investors as well as members of the public may cause a temporal rise in the prices [5]. In the real estate sector in Kenya, this seems to be the case. The rapid increase in housing prices without the support of the economics rules raises a red flag as it indicates the possibility of a bubble existence [6]. A study carried out by Smith, Sorensen, and Wickens while addressing bubbles in the stock market says 
that stock market bubbles exist when the stock prices increase continuously in a way that is inconsistent with the fundamentals and then drops dramatically [7]. Therefore, a housing bubble can be caused by a rapid growth or increase in property prices until they reach unsustainable levels being forced to decline drastically.

The increasing trend of a bubble is referred to as a boom, while the decreasing trend of a bubble is referred to as a burst. The burst of a bubble can be very harmful to any economy as it can result in a financial crisis. The global financial crisis which happened in 2008 is a good example where the housing prices had risen to the peak in early 2006 then started to fall later that year and also early 2007 [8]. This rise had been caused by an increase in stock prices which led to an increase in demand for housing. This resulted in a rise in housing prices and raised expectations that there would always be an upward trend in the house prices. Many people then bought houses at an exaggerated price and continued until 2007 when there was an oversupply and could not be supported by the prices. In 2008 the prices had declined by $30 \%$ from the peak [8]. As of December 2008, it was reported that Case and Shiller home price index experienced the largest price drop in the past.

\section{Literature Review}

\subsection{Dynamics of the Real Estate Sector}

Several studies have been conducted to find out whether there exists a relationship between housing and the overall economy of a country. To investigate house price dynamics, researchers have used various tests based on Vector error correction model (VECM). Granger causality, impulse response functions, and variance decomposition are some of the tests that have been commonly used

Bulut examined the relationship between demand and supply in the real estate market in Turkey using annual data taken from 1970 to 2007 [9]. The study applied a cointegration test and Vector error correction model. The findings of the study indicated that there were expected signs for long term and short term relationships.

A study by Kargi investigated the association between economic development and construction industry in the Turkish Economy [10]. The study used multiple linear regression, bivariate correlation analysis, and Granger causality tests and utilized Turkish housing data from 2000 2012. The study found out that the growth process supported the construction industry. It was also found that the Inflation and construction sector had a negative correlation with economic performance. The findings from Granger causality tests, variance decomposition and impulse response functions for the data taken from 2002 - 2007 revealed a shock to several macroeconomic variables namely: volume of housing loans, interest rate, and national income. All were found to affect the activities in the housing market.

A more recent study by Panagiotis and Printzis used the VECM approach to investigate whether there existed a relationship between macroeconomic determinants and the housing prices in Greece [11]. The data used was collected on a monthly basis from the year 1997 to 2014. The findings revealed the presence of a long-term association between macroeconomic determinants and the housing prices.

\subsection{Testing Real estate Bubbles}

In the recent past, several methods have been applied in testing real estate bubbles. In a study, Phillips and $\mathrm{Yu}$ suggested a supremum Augmented Dickey-Fuller test (SADF) also referred to as right-tailed forward recursive test [12]. This method implements the forward (right-tailed) Dickey-Fuller test recurrently on an onward increasing sample series and inferencing centered on the supremum value of the consistent dickey fuller statistic series. This method is also able to determine real-time estimations of the beginning and the ending dates of the bubble. However, this method is only able to analyze a single bubble episode. Therefore, Phillips, Shi and Yu proposed sup-sup DickeyFuller test [13]. This test is based on the same idea as PWY in that it implements a right tailed Dickey-Fuller test moreover this method outspreads the sample series by fluctuating both the first and termination points of the sample over a reasonable choice of flexible windows other than stating the initial point of each regression window to be the first observation of the full sample.

In a comparative study carried out by Shen on price bubbles in the housing sector in Beijing, Shanghai and Hong Kong, the study sought to estimate bubble size from January 1997 to December 2003 for Beijing, January 2001 to December 2003 for Shanghai and January 1990 to September 2003 for Hong Kong [14]. The bubble size was determined by obtaining differences between the estimated or fundamental and actual house prices. The fundamental house prices were determined through supply and demand model by Quigley (1999) where the model was as follows.

Deng et al. in a study to investigate whether bubbles migrated from stock to housing market in China between 2005 and 2010 used the recursive explosive - root method proposed by Phillips et al. to detect and date speculative bubbles in both markets [21]. The study again proceeded to implement the Greenaway-McGrevy and Phillips test to detect whether there was migration between the two types of bubbles. The findings revealed that there was a significant migration of bubble from the stock to the housing market in the year 2009 and a temporary spillover in the year 2007.

In Israel, home prices were found to appreciate by $50 \%$ on average between 2008 and 2013. This led to a study by Caspi to examine whether this indicated the presence of a state or regional bubble [22]. This was met by applying econometric tests for explosive behavior to quality-adjusted state- and regional-level data on the home price to rent ratio. The study controlled for various vital factors among which included interest rates, income and the leverage ratio. The findings indicated that the state- and regional-level data were inconsistent with a housing bubble scenario. 


\section{Methodology}

\subsection{Stationarity Test}

Stationarity of a time series is an important concept in modeling financial data. A stationary time series is said to be one without an orderly change in mean, one without a regular change in variance and one whose periodic deviations have strictly been eliminated.

Having two non-stationary series, $\mathrm{x}$ and $\mathrm{y}$ and modeling them using simple OLS method, then the estimates obtained from these series may result in a spurious regression.

A non-stationary series may be differenced to become give stationary series. The number of times to difference is determined by the order in which the series is integrated. For example, a series integrated of order one (I (1)) needs to be differenced once to become stationary. A series that is stationary is referred to as stationary in level.

$$
\begin{gathered}
\mathrm{x} \text { level }=\mathrm{xt} \\
\mathrm{x} 1^{\text {st }} \text { differencing }=\mathrm{xt}-\mathrm{xt}-1
\end{gathered}
$$

and so on.

To test for stationarity of the variables, this study used Augmented Dickey-Fuller (ADF) test suggested by [15]. Considering an AR model,

$$
\Delta \mathrm{x}_{\mathrm{t}}=(\rho-1) \mathrm{x}_{\mathrm{t}-1}+\varepsilon_{\mathrm{t}}
$$

Where $x_{t}$ is the time series this case referring to the real estate house prices and $\varepsilon_{\mathrm{t}}$ is a sequence of independent normal random variables with mean 0 and a constant variance.

\subsection{Cointegration Test}

When two series integrated of the same order are linearly combined to give a stationary series, the two series are said to be cointegrated. To test for cointegration, the study uses the
Johansen-Juselius procedure suggested by Alexander [17]. This technique uses Maximum Eigenvalue test and Trace test to determine the number of cointegrating equations. The null hypothesis under Maximum Eigenvalue test states that there are $r$ cointegrating equations versus the alternative hypothesis that states that there are $r+1$ cointegrating equations where $r$ $=0,1,2, \ldots, \mathrm{n}-1$. The test statistic is computed as:

$$
\operatorname{LR}_{\max }(\mathrm{r} / \mathrm{n}+1)-\left(-\mathrm{T}^{*} \log (1-\hat{\lambda})\right)
$$

Where $\mathrm{T}$ is the number of observations and $\lambda$ is the Maximum Eigenvalue.

Under Trace test, the null hypothesis states that there are $r$ cointegrating equations where $\mathrm{r}=0,1,2, \ldots, \mathrm{n}-1$. The trace statistic is computed as:

$$
\operatorname{LR}_{\text {trace }}(\mathrm{r} / \mathrm{n})-\left(-\mathrm{T}^{*} \sum \log (1-\widehat{\lambda})\right)
$$

In the case where Trace test yields different results from that of Maximum Eigenvalue test, [18] suggested that the results of Trace test be preferred.

If there exists cointegration between time series, it is then concluded that there exist a long-run relationship.

\subsection{Vector Error Correction (VEC) Model}

This model was used to determine long-term and short term real estate price dynamics in the Kenyan real estate Market given some selected macroeconomic variables.

Vector error correction model is performed to evaluate short-run relationships between the variables of interest. This model is performed on co-integrating series, otherwise, VECM is not applied and the study proceeds to perform Granger causality tests to establish determine whether the macroeconomic variables granger causes real estate prices. The VECM equation is given as:

$$
\Delta \mathrm{Y}_{\mathrm{t}}=\alpha_{1}+\mathrm{P}_{1} \mathrm{e}_{1}+\sum_{i=0}^{n} \beta_{\mathrm{i}} \Delta \mathrm{Y}_{\mathrm{t}-\mathrm{i}}+\sum_{i=0}^{n} \quad \text { i } \Delta \mathrm{X}_{\mathrm{t}-\mathrm{i}}+\sum_{i=0}^{n} \gamma \mathrm{Z}_{\mathrm{t}-\mathrm{i}}
$$

$$
\Delta \mathrm{X}_{\mathrm{t}}=\alpha_{2}+\mathrm{P}_{2} \mathrm{e}_{\mathrm{i}-1}+\sum_{i=0}^{n} \beta_{\mathrm{i}} \Delta \mathrm{Y}_{\mathrm{t}-\mathrm{i}}+\sum_{i=0}^{n} \quad \text { i } \Delta \mathrm{X}_{\mathrm{t}-\mathrm{i}}+\sum_{i=0}^{n} \gamma \mathrm{Z}_{\mathrm{t}-\mathrm{I}}
$$

In the above equations, $e_{i-1}$ is the error correction term indicating speed adjustment. If the term is statistically significant and negative, then any short-run variations of macroeconomic variables give rise to a stable long-run relationship with real estate prices.

\subsection{Granger-Causality}

Granger causality test is a bivariate test. Given two variables $\mathrm{X}$ and $\mathrm{Y}$, the test examines whether $\mathrm{X}$ Granger causes $\mathrm{Y}$ and vice versa. The equation of this test can be expressed as follows:

$\Delta \mathrm{X}_{\mathrm{t}}=\alpha_{0}+\alpha_{1} \mathrm{Yt}-1+\ldots \alpha_{1} \mathrm{Yt}-\mathrm{i}+\beta 1 \mathrm{Xt}-1+\ldots+\beta 1 \mathrm{Xt}-\mathrm{i}+\mu$

Where $X_{t}$ and $Y_{t}$ are time series and $\mu$ is a white noise.

\subsection{Phillips, Shi and Yu (PSY) Method}

This method was suggested by [13]. The method in the context of Dickey-Fuller test is based on the following regression:

$$
\Delta \mathrm{f}_{\mathrm{t}}=\mu+(\rho-1) \mathrm{f}_{\mathrm{t}-1}+\varepsilon_{\mathrm{t}}
$$

Where $\mathrm{f}_{\mathrm{t}}$ is the time series of the real estate price and $\varepsilon_{t}$ is the error term. This test states the hypothesis as follows:

H0: $\rho=1$ versus the alternative hypothesis H1: $\rho>1$ (explosiveness)

The hypothesis is stated differently from that of a standard stationarity test where the alternative hypothesis indicates stationarity.

A bubble is said to exist if the explosiveness manifest.

\subsection{Measure of Bubble Size}

The size of the bubble was then measured following [18] and [20] method. It was developed with the assumption that housing markets the prices occur through the equilibrium of 
supply and demand. In this case, the model is as follows:

$$
f t=f\left(\mathrm{x}_{\mathrm{t}}\right)
$$

Where $f_{t}$ is the fundamental real estate price which is the predicted value and $x_{t}$ represents the macroeconomic variables. The fundamental/predicted prices are taken to be a function of the macroeconomic variables. The bubble size is then calculated as shown in the equation and is represented as a percentage:

$$
f t=\frac{p t-f t}{f t} * 100 \%
$$

Where $b t$ is the bubble size, $p t$ is the actual price of a real estate and $f t$ is the fundamental real estate price or the estimated real estate price.

\section{Data Description}

To investigate real estate bubbles in the Kenyan market, the study applied data on; house prices, loans to real estate (RELOANS), Gross domestic product (GDP), Building cost (BC), lending rates (LENDRATES) and Diaspora
Remittances (DASPREM). Again, house price to rent ratio was also calculated which was later used to examine a bubble. It was calculated as:

$$
\frac{\text { House Price }}{\text { (monthly rent } * 12 \text { months) }}
$$

The data was collected at quarterly intervals over a period of 55 successive quarters from January 2004 to September 2017. The data was obtained from Central Bank of Kenya (CBK), Kenya National Bureau of Statistics (KNBS), and Hass Consult Limited. The variables were then transformed into indices using the first quarter of 2004 as the standard value and then converted to natural logarithms. This was done to ease the complexity of working with large figures.

\section{Empirical Result}

Table 1 and Figure 1 show the details of the data where the Table presented the mean, median, maximum, minimum, standard deviation, skewness, and kurtosis of the variables while the figure showed time series plots of each variable.

Table 1. Descriptive statistics.

\begin{tabular}{lllllll}
\hline & $\operatorname{logBC}$ & $\operatorname{logDASPREM}$ & $\log G D P$ & $\operatorname{logHP}$ & logLENDRATES & logRELOANS \\
\hline Mean & 4.98 & 5.50 & 4.90 & 4.88 & 5.21 & 5.70 \\
Median & 4.97 & 5.38 & 5.28 & 5.31 & 4.66 \\
Max & 5.32 & 6.39 & 4.59 & 5.73 & 5.03 \\
Min & 4.61 & 4.57 & 0.1894 & 4.59 & 4.53 \\
SD & 0.2189 & 0.5700 & 0.188 & 0.3772 & 0.1269 \\
Skewness & -0.105 & -0.0599 & 2.16 & -0.316 & 1.043 \\
Kurtosis & 1.85 & 1.63 & 55 & 1.70 & 3.36 \\
N & 55 & 55 & 55 & 5.61 \\
\hline
\end{tabular}

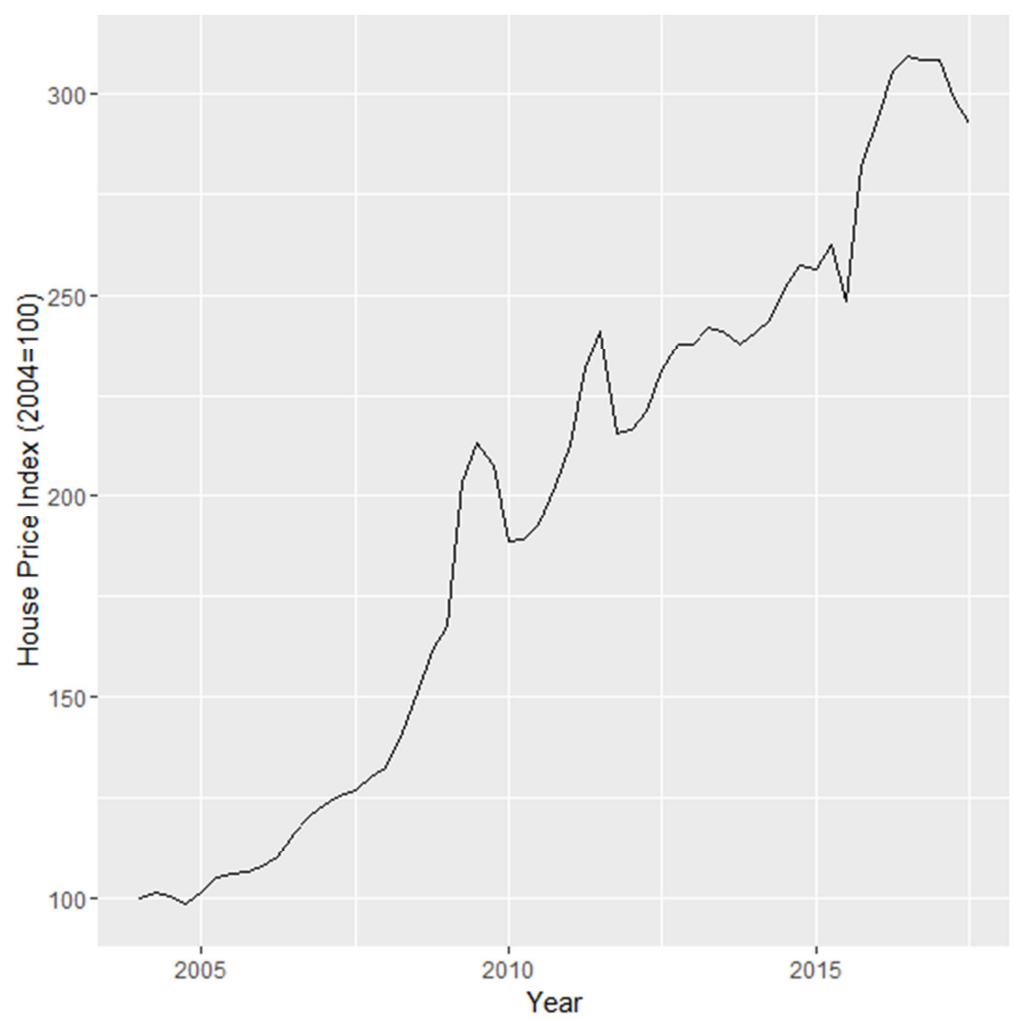




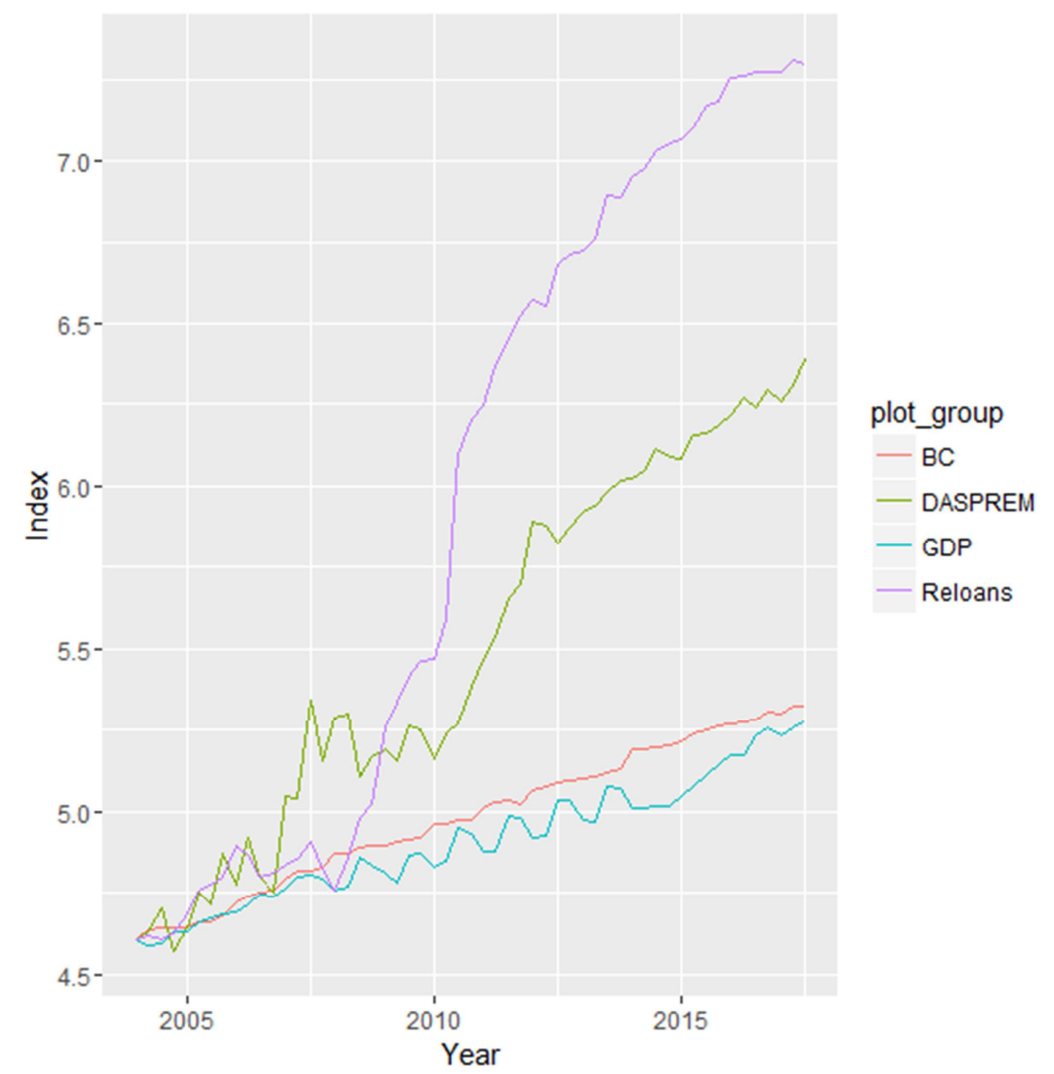

Figure 1. Time series plots for the monthly data of house prices and macro-economic variables.

Figure 1 shows that house prices were seen to have a consistent upward trend from the year 2004 to 2017 . This was also seen in the macroeconomic variables.

\subsection{Stationarity Test}

The results in Table 2 clearly shows that the time series were not stationary in level but in the first difference. The null hypothesis of ADF test was rejected for all variables in their first differences. Thus, all the variables were integrated of the same order that is I (1).

Table 2. ADF tests results for 2004:Q1 to 2017:Q3.

\begin{tabular}{llllll}
\hline \multirow{2}{*}{ Variable } & Level & \multicolumn{5}{c}{ Differenced } & Results \\
\cline { 2 - 6 } & t-stat & p-value & t-stat & p-value & I (1) \\
\hline Log HP & -1.1985 & 0.6688 & -5.5861 & $<0.0001$ & I (1) \\
Log BC & -0.6854 & 0.8414 & -8.9985 & $<0.0001$ & I (1) \\
Log DASPREM & -0.4939 & 0.8840 & -10.9878 & $<0.0001$ & I (1) \\
Log GDP & 0.0143 & 0.9553 & -3.5104 & 0.0117 & I (1) \\
Log LENDRATES & -2.486 & 0.1245 & -5.0839 & 0.0001 & \\
\hline
\end{tabular}

\subsection{Determination of Lags}

Table 3 presents lag-order selection criteria. The result shows 4 as the optimal number of lags. Hence, the study proceeds to perform other tests with 4 lags.

Table 3. Lag length selection.

\begin{tabular}{llll}
\hline Lag & AIC & HQ & SC \\
\hline 0 & -9.7584 & -9.5311 & -9.6716 \\
1 & -20.9672 & -19.5687 & -17.7431 \\
2 & -20.6977 & -19.0145 & -16.3464 \\
3 & -20.6646 & -19.6578 & -16.1472 \\
4 & $-21.8290^{*}$ & $-20.3593^{*}$ & $-19.3763^{*}$ \\
\hline
\end{tabular}

* is the optimal lag selected 


\subsection{Cointegration Test}

Next, the study performed a cointegration test between nonstationary variables. To test for co-integration, Johansen cointegration test was employed. The results included both the trace and maximum eigenvalue tests.

Table 4. Johansen cointegration test.

\begin{tabular}{lllll}
\hline Trace Test & & & & \\
\hline Hypothesized & & & & Trace Statistic \\
\hline No. of CE (s) & Eigenvalue & 84.58608 & 0.05 Critical Value & 0.2284 \\
\hline None & 0.506324 & 47.88059 & 95.75366 & 0.7266 \\
At most 1 & 0.356495 & 24.95764 & 69.81889 & 0.9198 \\
At most 2 & 0.212466 & 12.53753 & 47.85613 & 0.9115 \\
At most 3 & 0.149489 & 4.117775 & 29.79707 & 0.8938 \\
At most 4 & 0.073790 & 0.131747 & 15.49471 & 0.7166 \\
At most 5 & 0.002530 & 3.841466 & \\
\hline
\end{tabular}

Table 5. Johansen cointegration test.

\begin{tabular}{lllll}
\hline Maximum Eigenvalue Test & & & \\
\hline Hypothesized & & & & p-value \\
\hline No. of CE (s) & Eigenvalue & max-Eigen Statistic & 0.05 Critical Value & 0.1143 \\
\hline None & 0.506324 & 36.70550 & 40.07757 & 0.5363 \\
At most 1 & 0.356495 & 22.92295 & 33.87687 & 0.9145 \\
At most 2 & 0.212466 & 12.42010 & 27.58434 & 0.8762 \\
At most 3 & 0.149489 & 8.419759 & 21.13162 & 0.8608 \\
At most 4 & 0.073790 & 3.986028 & 14.26460 & 0.7166 \\
At most 5 & 0.002530 & 0.131747 & 3.841466 & \\
\hline
\end{tabular}

The results in Table 4 and Table 5 indicated that there were no co-integrating equations. This was because the null hypothesis was not rejected at 5\% level of significance. Since co-integrations did not exist, the study could not proceed to perform a vector error correction model (VECM). The absence of the cointegrating equation (s) indicates the presence of a real estate bubble [19]. The study then tested for Granger causality.

\subsection{Granger Causality Tests}

Granger causality test was conducted to test for direction and cointegration between two series. Macroeconomic variables were examined to test whether they Granger caused House prices. Estimation results were presented in Table 6.

Table 6. Granger causality test.

\begin{tabular}{lll}
\hline Null Hypothesis $\left(\mathbf{H}_{\mathbf{0}}\right)$ & Statistic & p-value \\
\hline BC does not Granger Cause HP & 1.87430 & 0.1645 \\
DASPREM does not Granger Cause HP & 0.35205 & 0.7050 \\
GDP does not Granger Cause HP & 0.17842 & 0.8371 \\
LENDRATES does not Granger Cause HP & 1.10611 & 0.3391 \\
RELOANS does not Granger Cause LNHP & 0.92185 & 0.4047 \\
\hline
\end{tabular}

At 5\% significance level, the results revealed that all the identified macroeconomic variables did not Granger cause the house prices. This was indicated by an insignificant $\mathrm{p}$ value (all the p-values were greater than 0.05 and). Thus, the null hypothesis failed to be rejected.

\subsection{Generalized Sup ADF Test}

This test assumes that upon the occurrence of a bubble, prices explode. This test is a changed version of the ADF test and a right-tailed unit root test which captures the explosiveness of the time series, house prices in this study.

Under this, the test was applied on the price to rent ratio and the regression was performed 2000 times. The results were then presented in Table 7 and Figure 2

The results in Table 7 indicated the presence of a Bubble having concluded the alternative hypothesis that there is explosiveness in the Kenya house price to rent ratio.

Table 7. GSADF test statistics for Kenyan real house price-to-rent ratio.

\begin{tabular}{lllll}
\hline \multirow{2}{*}{ Data } & Test stat. & Critical values & & \\
\cline { 3 - 5 } & & $\mathbf{9 0 \%}$ & $\mathbf{9 5 \%}$ & $\mathbf{9 9 \%}$ \\
\hline Price-Rent-Ratio & 2.7573 & 1.0203 & 1.5690 & 1.8786 \\
\hline
\end{tabular}


The results in Figure 2 indicated two bubble periods in the Kenyan real estate market. One occurred between 2009 the third quarter to 2010 the first quarter while the second one occurred in 2011 the second quarter and 2011 the third quarter. There was also an indication of a Bubble during the second quarter of 2014.

In summary, GSADF test results confirm the recent exuberance in the house prices which is a sign of a bubble.

GSADF test

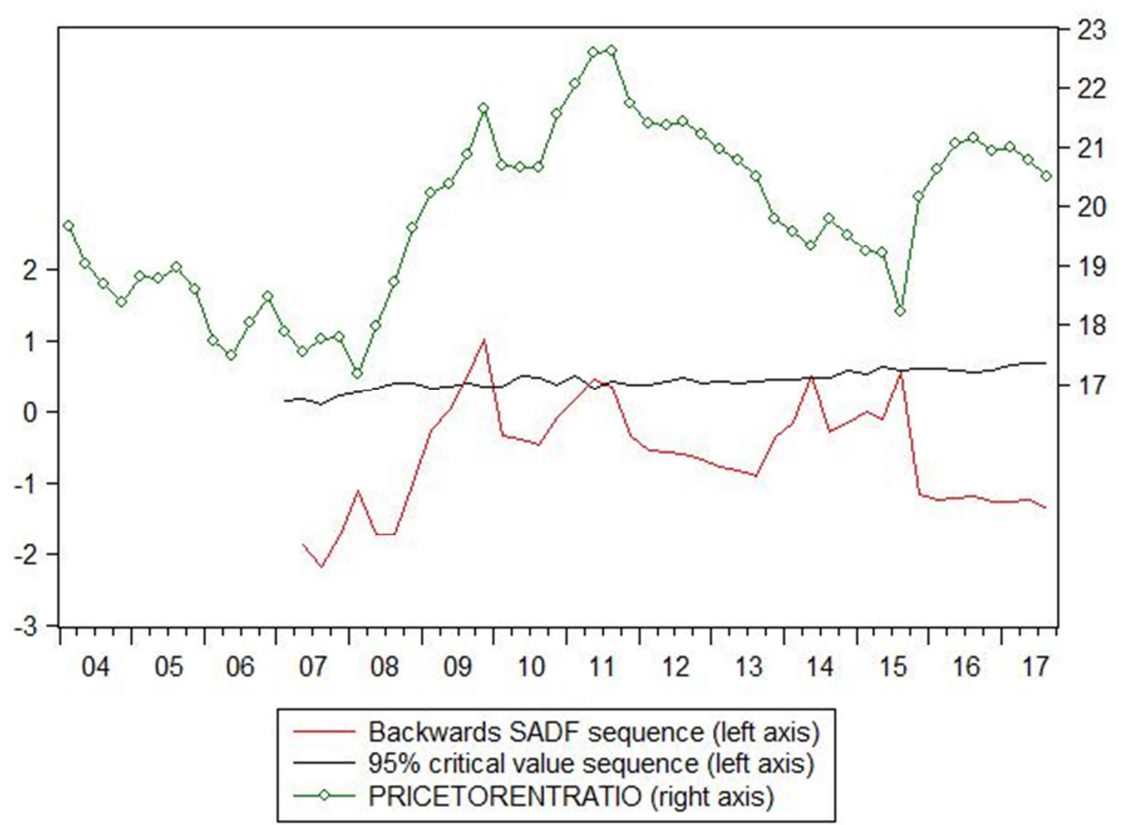

Figure 2. Bubble periods in the Kenyan price-to-rent ratio.

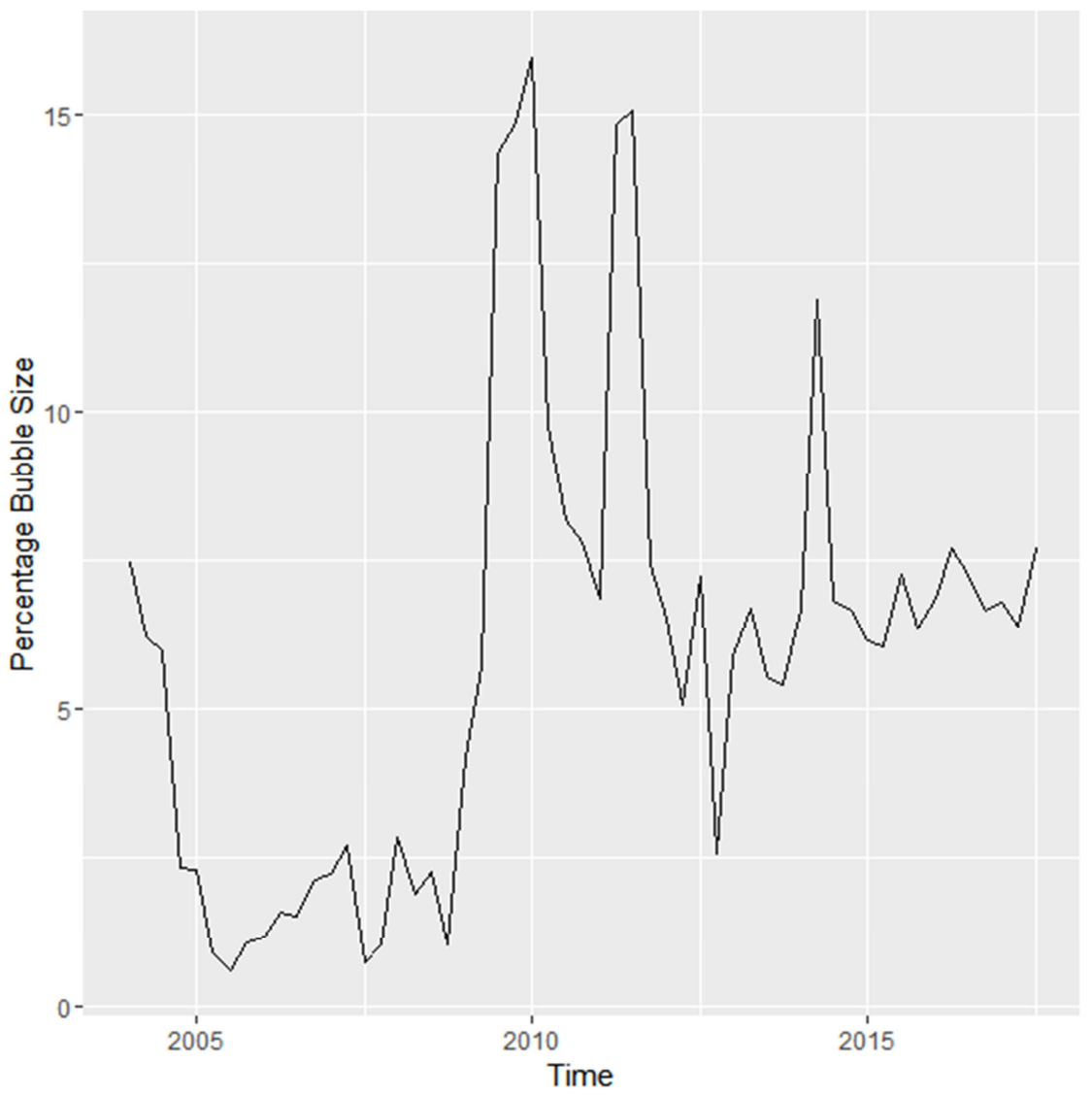

Figure 3. Bubble size in percentage. 


\subsection{Bubble Size Determination}

The study proceeded to measure the bubble size following the method by Hui and Yue as cited in [18]. It was assumed that that in the Kenyan real estate market, the prices happen through an equilibrium of demand and supply. An OLS method is used to predict house prices through which the difference between actual and predicted house prices is then taken to be a Bubble term. OLS results are presented in Table 8

Table 8. Regression Results.

\begin{tabular}{lllll}
\hline Variable & Coefficient & Std. error & t-stat & prob \\
\hline C & -179.50 & 25.65 & 3.514 & 0.001 \\
DASPREM & 0.264 & 0.073 & 3.625 & 0.001 \\
LENDRATES & 0.324 & 0.115 & 2.821 & 0.007 \\
RELOANS & 0.050 & 0.018 & 2.767 & 0.008 \\
GDP & 0.569 & 0.233 & 2.446 & 0.018 \\
BC & 2.041 & 0.271 & 7.532 & 0.0001 \\
R-square & 0.986 & & & \\
Adjusted R-square & 0.975 & & & \\
\hline
\end{tabular}

Loans to real estate, Gross domestic product (GDP), Building cost, lending rates, and Diaspora Remittances were found to be significant predictors. The predicted house prices were then obtained and the difference with the actual values obtained to get a bubble term.

The Bubble term was computed as a percentage and then presented in a plot as shown in Figure 3.

The results show that the accumulated percentage of the house price bubble was at the peak in 2009, 2011 and 2014 which was approximately 15 percent. This confirms the bubble suggestion in those years. However, [20] reasoned that there was a bubble in the housing sector in Perth, Australia in the year 2006 and the bubble represented 25\% of the house price.

\section{Conclusion}

It can be concluded that macroeconomic variables namely: loans to real estate, Gross domestic product (GDP), Building cost, lending rates, and Diaspora Remittances did not have a relationship and did not Granger cause housing prices. Cointegration test indicated an absence of cointegrating equations which indicated the presence of a real estate bubble. This was also confirmed by GSADF right-tailed test which went ahead and revealed that the bubble existed in two time periods Again, the study findings revealed the presence of a housing bubble one between 2009 the third quarter to 2010 the first quarter and another one occurred in 2011 the second quarter and 2011 the third quarter. The bubble was at the peak in 2009 and 2011 which attributed to $15 \%$ of the house prices in the two time periods. For further study, researchers should conduct a similar study detecting house price bubbles but in this case per county to see the most affected region.

\section{References}

[1] KNBS, D. G. (2014). Kenya Facts and Figure 2014 (Booklet) Nairobi Kenya: Kenya National Bureau of Statistics.

[2] CAHF (2012). Housing Finance in Africa. A review of Africa's housing finance markets (2012 Year Book). Midrand: Centre for Affordable Housing Finance in Africa. A division of the Finmark Trust.

[3] Knight, F. H. (2012). Risk, uncertainty and profit. Courier Corporation.

[4] Consult, H. (2014). Residential areas of Kenya.

[5] Case, K. E., \& Shiller, R. J. (2003). Is there a bubble in the housing market? Brookings papers on economic activity, 2003 (2), 299-342.

[6] Belke, A., Weidman, M. (2013). Monetary Policy, Stock Prices and Central Banks-Cross-Country Comparisons of Cointegrated VAR Models. Ruhr Economic Papers \#435.

[7] Smith, P. N., Sorensen, S., \& Wickens, M. R. (2008). General equilibrium theories of the equity risk premium: estimates and tests. Quantitative and Qualitative Analysis Social Sciences, 2, 35-66.

[8] Baker, D. (2008). The housing bubble and the financial crisis. Real-world economics review, 46 (20), 73-81.

[9] Bulut, Z. B. (2009). Demand and supply of real estate market in Turkey: a cointegration analysis. Yayınlanmamış Yüksek Lisans Tezi. Ocak. Bilkent University.

[10] Kargi, B. (2013). Integration between the Economic Growth and the Construction Industry: A Time Series Analysis on Turkey (2000-2012).

[11] Panagiotis and Printzis (2015). Macroeconomic determinants of the housing market in Greece: a VECM approach. Hellenic Observatory, European Institute, London, UK.

[12] Phillips, P. C., \& Yu, J. (2011). Dating the timeline of financial bubbles during the subprime crisis. Quantitative Economics, 2 (3), 455-491.

[13] Phillips, P. C., Shi, S., \& Yu, J. (2015). Testing for multiple bubbles: Limit theory of real - time detectors. International Economic Review, 56 (4), 1079-1134.

[14] Shen, Y. (2006). Housing price bubbles in Hong Kong, Beijing and Shanghai: a comparative study, J. Real Estate Financ, 33, 299-327.

[15] Dickey, D. and W. Fuller, 1979. Distribution of the estimators for autoregressive time series with a Unit Root. J. the American Statistical Association, 74 (366): 427-431.

[16] Johansen, S. and K. Juselius, 1990. Maximum likelihood estimation and inference on cointegration with application to the demand for money. Oxford Bulletin of Economics and Statistics, 52 (2): 169-210.

[17] Alexander, C., 2001. Market models: A guide to financial data analysis. John Wiley \& Sons Ltd.

[18] Hui, E. C., \& Yue, S. (2006). Housing price bubbles in Hong Kong, Beijing and Shanghai: a comparative study. The Journal of Real Estate Finance and Economics, 33 (4), 299-327. 
[19] Arshanapalli, B., \& Nelson, W. (2008). A cointegration test to verify the housing bubble. The International Journal of Business and Finance Research, 2 (2), 35-43.

[20] Jiang, Heng, Yu Song, and Chunlu Liu. "House price bubble estimations in Australia's capital cities with market fundamentals." Pacific Rim Property Research Journal 17, no. 1 (2011): 132-156.
[21] Deng, Y., Girardin, E., Joyeux, R., \& Shi, S. (2017). Did bubbles migrate from the stock to the housing market in China between 2005 and 2010?. Pacific Economic Review, 22 (3), 276-292.

[22] Caspi, I. (2016). Testing for a housing bubble at the national and regional level: the case of Israel. Empirical Economics, 51 (2), 483-516. 